\title{
A University Archives and Records Management Program: Some Operational Guidelines
}

This article suggests some guidelines for the administration of the archives as a depository for the inactive official records of a college or university. Records scheduling and transmittal are discussed, as are suggestions for educating the users of such archives.

As the work of colleges and universiries grows increasingly complex, and as educational budgets become smaller, the significance of a university archival program with records management authority becomes increasingly apparent. Such programs are hardly new. Several university archives have justified their existence and budgetary allocations by assuming full responsibility for the management, appraisal, preservation, and destruction of institutional operating records. ${ }^{1}$ The advantages of an appropriately administered archival and records management program are obvious. Important administrative and historical records are protected against unauthorized or unwarranted destruction. Inactive records can be readily identified, removed from office filing cabinets, and transferred to low-cost storage facilities. Impressive savings can be realized in reduced filing equipment purchases and reclaimed office floor space.

Most college and university archives, however, were originally formed out of collections of materials used in the preparation of an institutional history

Mr. Saffady is archivist and records management specialist, Wayne State University, Detroit, Michigan. for a centennial or similar anniversary celebration. Few archives enjoy the luxury of an experienced staff of professional records management specialists. In fact, a recent survey by the College and University Archives Committee of the Society of American Archivists indicates that few archives enjoy the luxury of a full-time professional archivist. $^{2}$ Although colleges and universities generate an immense quantity and bewildering variety of records every day, the number of journal articles devoted to the administration of college and university archives is unfortunately small. ${ }^{3}$ The most noticeable gap appears in the area of greatest needguidelines designed to assist archivists and librarians with archival responsibilities in the initiation and operation of a successful archival and records management program. ${ }^{4}$ This article attempts to fill that gap by suggesting some appropriate administrative procedures in five important areas: program authority, records scheduling, records transmittal, reference service, and user education.

\section{Program Authority}

To be effective, an archival and records management program must have 
administrative support. Ideally, this support should take the form of a policy statement, made by an appropriate administrative officer, to the effect that: (1) records created by university administrators and faculty members in the performance of assigned administrative duties are the property of the university, ${ }^{5}$ (2) such records are not to be destroyed without the approval of the officials in charge of the office where the records are maintained and the university archivist, (3) the university archives is to be the official depository for records of enduring administrative and/or historical significance, and (4) the university archivist is to be the university official responsible for the identification and systematic transfer of inactive records from individual offices to the archives. Without such a strong statement of support, the archives cannot operate effectively.

\section{Records Scheduling}

A viable university archival and records management program begins with a recognition by the archivist and an understanding by university officials that many records should never be deposited in the archives. Active records that are referenced frequently belong in the office that uses them. Inactive records without further value should be destroyed. To identify groups of records of legal, administrative, or historical significance, the archivist must consult with officials in charge of the records in each office where records are maintained. The end product of such consultations should be a retention and disposal schedule.

The retention and disposal schedule is a document that lists the records maintained in each office by group (detailing subgroups when necessary), specifies the amount of time a given group of records should be retained in office filing cabinets, and indicates whether inactive records should be re- tained in an office storage area (when one is available) or transferred to the university archives for low-cost storage, later destruction, or permanent preservation. For groups of records without prolonged significance, the schedule should specify destruction after an appropriate period of time.

It is difficult to overestimate the importance of the consultation in the composition of the retention and disposal schedule. In scheduling records, the archivist is guided by legal and empirical parameters. Legal record retention requirements are fairly uniform and easy to master. Empirical parameters governing the needs of individual offices vary considerably. A simple form like a purchase order must be retained in one office to satisfy state statutes regarding contractual obligations, but can be destroyed in another office when the merchandise ordered is received. In some cases, offices will want to retain forms for their administrative value even though the legal retention period has elapsed. The records scheduling consultation should include the archivist and one or more of the officials in charge of the office where the records in question are maintained. Together they should review carefully and thoroughly the need to retain given groups of records and establish a time period when records of different types can be removed from office files and either destroyed or transferred to the archives. Admittedly, it is difficult and time-consuming to interview every university official who maintains records, but the time and energy invested in the composition of individual schedules will be repaid in a well-regulated system of retention and destruction. The only effective records schedule is one that meets the needs of both the individual office and the entire university. Schedules produced by cooperation are more likely to be observed than schedules produced by dictation. 6 
Once retention and disposal schedules are prepared, members of the office staff will be able to easily identify groups of records that should be periodically removed from office files and destroyed or transferred to the archives. This transfer becomes a matter of routine in all but the most unusual cases.

\section{Records Transmittal}

There are two steps in the actual transmittal of records to the university archives: packing and inventorying. To simplify archival operations and to ensure uniformity among shipments received from different university offices, it is most important that both of these steps be routinized. The archives should provide the transmitting office with storage containers, thereby eliminating the use of trans-files and oversized cartons. The office should understand that the use of standard-size containers allows for the most efficient utilization of available shelf space in the archival storage area. The archives must assume responsibility for minimizing whatever inconvenience might arise from the necessity of obtaining containers from a single, designated source. Offices should be informed that they must request containers a specified number of days or weeks in advance of anticipated transmittal date. The archives should furnish offices with a guide for estimating the number of containers required: if a standard record center container with inside dimensions of ten inches by twelve inches by fifteen inches is used, two containers will accommodate one legal-size file drawer. For letter-size files, three containers are required for every two drawers. Offices should be encouraged to use the standard container whenever possible. Records smaller than conventional letter or legal-size files can be packed in standard containers using the most practical arrangement possible. Special containers can be purchased to accommodate oversize materials such as bound ledgers, drawings, charts, and maps. It is important in such cases that the archivist inform the transmitting office that special containers will have to be ordered and that the office staff should notify the archives well in advance of anticipated shipment.

If records are to be referenced with a minimum of inconvenience, they must be packed properly. They should be placed in containers without disturbing the existing file arrangement. Records should not be forced or jammed into containers, and, if subsequent additions are expected, sufficient space should be allowed for interfiling. Detailed screening of files during packing should be discouraged. Obvious duplicates or items that have met retention requirements should be removed, but this should be done in cursory fashion, so as not to cancel the economic advantages gained by saving storage space. Clerical labor is invariably more costly than a few inches of space inside a storage container.

Each container must be properly labeled. Because the label and the files inside are the only things that distinguish one container from another in a wellmanaged archival storage area, the design of the label is most important. Space should be allowed for an accession number, container number (with an indication of the total number of containers in a given shipment, i.e., "number two of four," "number three of seventeen," etc.), the name of the transmitting office, and a description of the records packed inside.

The transmitting office should assume responsibility for documenting the transfer of records by completing an inventory of the items in each container. This inventory should be made on a form especially designed for that purpose. The form should contain space for the name and address of the transmitting office and the name and telephone extension of the person respon- 
sible for the preparation of the shipment. The actual inventory should consist of a listing of every file folder in every container by container number, folder number, and folder tab title. Additional space may be allowed for retention and disposal indications and special instructions detailing restrictions on the use of records. Space should also be provided for the registration of an accession number to be assigned when the shipment arrives at the archives. The archivist should assume responsibility for informing the transmitting office of the accession number assigned to each of its shipments so that it can be used in later reference requests.

The inventory form should be completed in duplicate. The original should accompany the records transmitted to the archives. The transmitting office should retain the copy. A multipart form that requires no additional carbon paper is ideal for this purpose. Each copy of the form can be clearly designated "archives copy" or "office copy." If at all possible, the inventory form, and all other forms used by the archives, should be designed by a professional forms analyst.

The completion of the inventory form is the most important step in the transmittal of records from the office to the archives. Without a properly completed inventory, later reference requests may prove difficult or impossible to fill.

\section{REFERENCE SERVICE}

Records sent to the archives will require occasional administrative reference. It is important that the archivist establish a clear understanding about the terms of access at the time the inventory and transmittal forms are completed. It is the responsibility of the transmitting office to indicate those persons or groups of persons who will be allowed to reference the records they have transferred to the archives. ${ }^{7}$ In many cases, a recommendation that persons desiring access to records receive the approval of the transmitting office is in everyone's best interest. Exceptions can be made in the case of records that receive public distribution, such as publications, reports, brochures, and printed programs, and records older than a specified number of years.

In many cases, the transmitting office's decision whether or not to cooperate willingly with the archives is frequently based on an assurance and proven record of reliable reference service. In most cases, three types of reference service will suffice: (1) information taken from records deposited in the archives, (2) copies of records deposited in the archives, or (3) return of records deposited in the archives to the transmitting office. In accepting requests for information from records deposited in the archives, the archivist should inform the person or persons making the request that members of the archives staff are not qualified to interpret the information the records contain. They will search files and report specific items of information only. If there is a need for interpretation, the office should request a copy of the required records. When such copies are provided, it is especially important that they not be refiled in office filing cabinets. They should be clearly marked "for information only" and the office should be instructed to destroy them when their usefulness is ended. A rubber stamp can be used for this purpose. If it is expected that records will be needed for more than purposes of information or for long periods of time, thus making filing necessary, the office should be encouraged to request return of the original records rather than copies.

Speed is usually the first criterion in the evaluation of archival reference service, and most offices prefer telephone requests to written ones. Both options should be available and a request for 
reference service form should be designed with both in mind. This form should allow space for an indication of the type of reference service desired (specifically, information, duplication, or outright return of records); space for a listing of the records or information requested by shipment accession number, container number, folder number, and folder tab title; and space for additional remarks or special instructions. In making requests for reference service, offices should be instructed to consult their copy of the completed inventory form to determine the probable container and folder location of the information or records they desire. If the inventory form and request for reference service are properly completed, most requests can be accommodated within a matter of minutes.

The request for reference service form should incorporate a receipt for records returned to the transmitting office. This receipt acknowledges the return of records and accounts for files listed on the inventory form but missing from containers. In addition, the completed request for reference service forms can be used by the archives staff to compile use statistics and anticipate future reference requirements.

\section{EDUCATING THE USER}

The advantages of a well-organized records management program are familiar to most archivists but never cease to amaze university officials who continue to view a university archives as a depository for curios. A records management program will never develop fully without appropriate publicity that clearly delineates the advantages of a sound program for the administration of institutional operating records and the role of the university archives in that program.

Few university officials are aware of the cost of maintaining inactive records in an active office, and it is the respon- sibility of the archivist to educate them. Most university offices file their records in vertical or lateral filing equipment. When guides and dividers are added, metal filing cabinets can usually hold about ten thousand individual documents, about eight cubic feet of records. Allowing for aisles and work space, a cabinet occupies about six square feet on the office floor. Floor space in most college and university buildings is rarely valued at less than six dollars per square foot. In many cases, it is much more valuable. This means that simply placing one metal file cabinet in an office costs more than thirty dollars, a figure which does not include the initial purchase price of the cabinet or the salaries of the clerical personnel required to maintain it. When the cabinet is full, a portion of the office budget must be spent to purchase another one. The result is increased expense and increased consumption of valuable floor space.

Bulky file cabinets filled with infrequently referenced records create additional difficulties. It is much easier to misfile papers in crowded file drawers and more difficult to find lost items. Organization of file classification systems, especially in subject files, is complicated. The resulting wasted time and effort increase the expense of office operations.

Even though they are not frequently referenced, inactive records contain important information that must be retained and protected. It is difficult to justify the expense of filing them in metal file cabinets that occupy valuable floor space in crowded offices, but piling them up in closets or dark basements where they might be lost or inadvertently destroyed could prove even more costly. Inactive records must be stored under conditions compatible with both economy and security.

A university archives, when properly organized and administered, can satisfy 
both conditions. Few university officials can fail to be persuaded by a well-presented statement of the archival program's rationale. The best solution to the problem of inactive records is to remove them from expensive office filing equipment and transfer them to a secure central storage facility where they can be stored economically and retrieved quickly when and if they are needed. The archivist should demonstrate the possibility of significant monetary savings when records are regularly and systematically transferred from offices to the archives. $^{8}$ In a university office, the cost of metal filing equipment large enough to store one cubic foot of records-about twelve hundred individual documents-is about thirteen dollars. In the standard records container used in combination with appropriate shelving, the same cubic foot of records can be stored for less than fifty cents. In a busy office, it is impossible to achieve maximum storage density. If vertical or lateral filing equipment is used, the space between the top of the cabinet and the ceiling of the room is usually wasted. Additional space must be allowed for extended drawers, work room, and aisles. A well-organized archives can utilize a shelving arrangement designed to achieve maximum utilization of available space, frequently storing over forty thousand documents in the amount of floor space occupied by a metal file cabinet that can hold only ten thousand.

Regular and systematic removal of inactive records from office files should virtually eliminate additional filing equipment purchases. In addition, the work of filing should be greatly simplified, thereby increasing the efficiency of available clerical personnel. Many offices are able to realize a sizeable gain in the amount of available floor space as areas previously occupied by paper can be reclaimed for people. In an age of budgetary constraints, these facts speak eloquently for themselves. Equally important, but more difficult to measure in terms of monetary value, important records of administrative and historical significance will be appraised and preserved by professional records administrators and afforded special protection against loss or inadvertent destruction.

\section{REFERENCES}

1. Cf. Clifford K. Shipton, "College Archives and Academic Research," American Archivist 27:395-96 (1964): "We decided that the way to justify the existence of the Harvard University Archives (and obtain a good appropriation) was to furnish records management service. This was a great success. Once when President James Conant said, 'We must economize; starting alphabetically, Archives', several department heads whom I had never met spoke up and said, 'You can't cut the Archives; it would cost us more to do the work they are doing for us'." On the same point, see Clifford K. Shipton, "The Harvard University Archives: Goal and Function," Harvard Library Bulletin 1:102 (1947); Fulmer Mood and Vernon Carstensen, "University Records and Their Relation to General University Administration," College and Research Libraries 11:337-45 (1950); Dwight H. Wilson, "No Ivory Tow- er: The Administration of a College or University Archives," College and Research $\mathrm{Li}$ braries 13:215-22 (1952).

2. College and University Archives in the United States and Canada (Ann Arbor: The Society of American Archivists, 1972), p.iv: "It is unfortunate that there are comparatively few full-time university archivists and that this is a field where the profession has a great deal of work to do."

3. Helen L. Chatfield, "College and University Archives: A Bibliographic Review," American Archivist 28:101-8 (1965), was the last review of the literature.

4. The College and University Archives Committee of the Society of American Archivists recently conducted a survey of American and Canadian university archival programs to determine what types of forms they utilize in the implementation of their programs. Respondents in the portion of the survey for 


\section{0 / College d Research Libraries • May 1974}

which I was responsible all expressed an interest in and a need for guidance in the area of daily program management. In view of the fact that a number of institutions plan to initiate archival programs in the coming years, the need for assistance should be even greater.

5. A university archives may, of course, contain nonofficial records, like the personal papers of faculty members and alumni, but such records are usually of historical rather than administrative interest. Cf. Henry J. Browne, "An Appeal for Archives in Institutions of Higher Learning," American Archivist 16: 224 (1953); Ernst Posner, "The College and University Archives in the United States," in Archives and the Public Interest (Washington, D.C.: Public Affairs Press, 1967), p.151.

6. On records scheduling, cf. Joseph L. Kish,
Records Retention Step-By-Step (New York: Systems Press, 1972); Corporate Records Retention, 3 vols. (New York: Financial Executives Institute); Modern Office Procedures (April 1969); William F. Schmidt and Sarah J. Wilson, "A Practical Approach to University Records Management," American Archivist 31:247-64 (1968).

7. Cf. Herbert Finch, "The Problem of Confidentiality in a College Archives," American Archivist 31:239-42 (1968).

8. All of the figures used here are based on our actual experiences at Wayne State University and are, if anything, a bit conservative. In some offices, it would be possible to demonstrate far more dramatic savings. Realtors specializing in industrial and commercial office space can provide information about the value of floor space in a given location. 